\title{
Novel Approach to Synthesize Nanostructured Gallium Oxide for Devices Operating in Harsh Environmental Conditions
}

\author{
Badriyah Alhalaili ${ }^{1}$, Ruxandra Vidu ${ }^{2,3, * \mathbb{C}}$, Ileana Nicoleta Popescu ${ }^{4,5, *(\mathbb{C})}$, Dhanu Radha Samyamanthula ${ }^{6}$ \\ and M. Saif Islam ${ }^{3}$ \\ 1 Nanotechnology and Advanced Materials Program, Kuwait Institute for Scientific Research, P.O. Box 24885, \\ Safat 13109, Kuwait; bhalaili@kisr.edu.kw \\ 2 Faculty of Materials Science and Engineering, University POLITEHNICA of Bucharest, \\ 060042 Bucharest, Romania \\ 3 Department of Electrical and Computer Engineering, University of California Davis, Davis, CA 95616, USA; \\ sislam@ucdavis.edu \\ 4 Faculty of Materials Engineering and Mechanics, Valahia University of Targoviste, 13 Aleea Sinaia Street, \\ 130004 Targoviste, Romania \\ 5 The Scientific and Technological Multidisciplinary Research Institute (ICSTM-UVT), \\ Valahia University of Targoviste, 13 Aleea Sinaia Street, 130004 Targoviste, Romania \\ 6 Water Research Center, Kuwait Institute for Scientific Research, P.O. Box 24885, Safat 13109, Kuwait; \\ vdhanuradha@kisr.edu.kw \\ * Correspondence: rvidu@ucdavis.edu (R.V.); pinicoleta24@yahoo.com or \\ ileana.nicoleta.popescu@valahia.ro (I.N.P.)
}

Citation: Alhalaili, B.; Vidu, R.; Popescu, I.N.; Samyamanthula, D.R.; Islam, M.S. Novel Approach to Synthesize Nanostructured Gallium Oxide for Devices Operating in Harsh Environmental Conditions. Sustainability 2021, 13, 10197. https:/ / doi.org/10.3390/su131810197

Academic Editor: Antonio Caggiano

Received: 7 August 2021

Accepted: 10 September 2021

Published: 13 September 2021

Publisher's Note: MDPI stays neutral with regard to jurisdictional claims in published maps and institutional affiliations.

Copyright: (c) 2021 by the authors. Licensee MDPI, Basel, Switzerland. This article is an open access article distributed under the terms and conditions of the Creative Commons Attribution (CC BY) license (https:/ / creativecommons.org/licenses/by/ $4.0 /)$.

\begin{abstract}
The importance of $\mathrm{Ga}_{2} \mathrm{O}_{3}$-based material for harsh environmental applications has attracted the interest of researchers in exploring various fabrication and growth techniques of $\mathrm{Ga}_{2} \mathrm{O}_{3}$-based nanomaterials using effective and low-cost processes. Herein, a demonstration to improve the wettability of liquid gallium on a rough silicon surface is presented. To control the roughness process, the silicon surface was patterned and groove-shape structures on the silicon were created using a photoelectrochemical (PEC) etching technique. Gallium oxide nanostructures were grown by thermal oxidation from liquid Ga in the presence and the absence of a silver thin film used as a catalyst. Scanning Electron Microscopy (SEM) was used to observe the morphology of the nanostructures grown on the roughed surface of the silicon substrate. The conformal deposition of $\mathrm{Ga}_{2} \mathrm{O}_{3}$ nanostructures inside the grooves of the PEC etched silicon surface was observed. The presence of $\mathrm{Ag}$ catalyst was found to completely change the morphology of $\mathrm{Ga}_{2} \mathrm{O}_{3}$. This method is recommended for the sustainable and low-cost synthesis of nanostructured gallium oxide for applications, including gas sensing.
\end{abstract}

Keywords: $\mathrm{Ga}_{2} \mathrm{O}_{3}$ nanostructure; liquid Ga wettability; thin films; PEC etching; sustainable coating; SEM analysis; gas sensors; harsh environmental applications

\section{Introduction}

A considerable decrease in natural resources [1,2] has been observed in recent years, which requires immediate attention from researchers and the industry community. Environmental pollution is so severe at the moment that it requires significant technological advances that must be made as soon as possible. In this regard, the design and development of novel engineered materials exploiting micro/nanodevice fabrication and integrating various processes in clean technology [3-7] are the most significant ways to reduce pollution.

Among the various sources of pollution, significant gas pollution is caused both by economic activities, which generate air pollutants resulting from industrial processes (industrial pollutants) $[3,4,8,9]$ and pollution resulting from the emissions of gases/noxious substances from vehicles, aircraft, railways or naval vehicles, or other toxic gases from indoor/outdoor environments [10-12]. Therefore, there is a need to develop sensors 
and devices based on materials with excellent properties at high temperatures, which work in harsh environmental conditions [13]. In order to quickly and efficiently detect various gases in aggressive environments (i.e., high temperature, pressure and radiation, corrosive, explosive or toxic environment, etc. [13]), gas sensors made of materials with the required structural and electronic properties are essential for the sustainable detection of gas emissions in these particular harsh conditions [14].

Among the semiconductor materials used in the sensing industry, gallium oxide $\left(\mathrm{Ga}_{2} \mathrm{O}_{3}\right)$ offers exceptional structural stability and excellent chemical resistance at very high temperatures (above $1000{ }^{\circ} \mathrm{C}$ ) [15], thermal stability (most stable at temperatures above $750^{\circ} \mathrm{C}$ ) and has relatively low thermal conductivities as compared to $\mathrm{SiC}$, sapphire and $\mathrm{GaN}$ [16]. $\beta-\mathrm{Ga}_{2} \mathrm{O}_{3}$ gas sensors could be used in both oxidizing and reducing atmospheres. It can be used to detect organic vapors at temperatures under $700{ }^{\circ} \mathrm{C}$ through surface redox reactions [17]. Fleischer et al. [18] demonstrated that $\mathrm{Ga}_{2} \mathrm{O}_{3}$ gas sensors have stable electrical responses to $1 \% \mathrm{H}_{2}$ in synthetic air and $5 \% \mathrm{H}_{2}$ in a nitrogen atmosphere at $600{ }^{\circ} \mathrm{C}$. For the detection of reducing gases (e.g., $\mathrm{H}_{2}$, ethanol, $\mathrm{CO}, \mathrm{CH}_{4}$, etc.) various researchers have used $\beta-\mathrm{Ga}_{2} \mathrm{O}_{3}$ thin films $[16,18,19]$.

Recently, there has been growing interest in investigating efficient high-k gate dielectrics for flexible and stretchable electronics which are capable of providing a superior gate capacitance that could replace the current gate oxides, such as silicon dioxide. Effective dielectrics require a wide energy band-gap, a large gate leakage current, good interface quality, excellent process compatibility and high stability with the Si surface [20]. Different gate dielectric materials have been used for semiconductor devices, such as silicon dioxide $\left(\mathrm{SiO}_{2}\right)$, silicon nitride $\left(\mathrm{Si}_{3} \mathrm{~N}_{4}\right)$, aluminum oxide $\left(\mathrm{Al}_{2} \mathrm{O}_{3}\right)$, zirconium oxide $\left(\mathrm{ZrO}_{2}\right)$, hafnium oxide $\left(\mathrm{HfO}_{2}\right)$, aluminum nitride $(\mathrm{AlN})$ and gadolinium oxide $\left(\mathrm{Gd}_{2} \mathrm{O}_{3}\right)$ [21-25]. The gate dielectric of a metal oxide semiconductor (MOS) capacitor is essential for electrical devices due to its influence on the capacitance of the gate. To obtain a high gate capacitance, a material with a high dielectric constant should be used. $\mathrm{Ga}_{2} \mathrm{O}_{3}$ is a promising gate dielectric material with a dielectric constant of 9.93 and 10.2 [26], which is much higher than the dielectric constant of silicon dioxide (3.9) [27]. $\mathrm{Ga}_{2} \mathrm{O}_{3}$ has a high resistivity to carriers that tunnel at the interface between the gate and silicon, owing to its higher dielectric constant [28]. In addition, $\mathrm{Ga}_{2} \mathrm{O}_{3}$ has a wide bandgap $(\sim 4.9 \mathrm{eV})$ and high chemical and thermal stability, which makes $\mathrm{Ga}_{2} \mathrm{O}_{3}$ an interesting material in the study of high-k gate dielectrics.

$\mathrm{Ga}_{2} \mathrm{O}_{3}$ thin film has been demonstrated as a gate dielectric by a number of research groups [29-35]. However, so far, no study has been conducted to enhance the oxidation of liquid gallium's wettability to improve the coating of $\mathrm{Ga}_{2} \mathrm{O}_{3}$ on the surface of the substrate with inexpensive and sustainable processes. It has been shown by our group that coating the surface with a thin film of metallic material, such as silver, prior to the oxidation process leads to a more homogeneous coating and a denser nucleation of $\mathrm{Ga}_{2} \mathrm{O}_{3}$ due to the low contact angle [36]. The contact angles of $\mathrm{Ga}$ on a silver film and silicon substrate are $30^{\circ}$ and $73.9^{\circ}[37,38]$, respectively, resulting in a better wetting of Ga on Ag surface and the uniform growth of $\mathrm{Ga}_{2} \mathrm{O}_{3}$ nanowires. However, this process requires the sputtering technique, which increases the cost of the fabrication. Our approach is to explore other versatile and sustainable techniques to enhance the wetting property of liquid Ga on the surface of different substrates. Thermal oxidation is an inexpensive method to grow $\mathrm{Ga}_{2} \mathrm{O}_{3}$ thin film or nanowires, but the poor wettability of $\mathrm{Ga}$ on $\mathrm{Si}$ substrates limits the use of this process for electronic applications. To study the wettability of Ga and the growth morphology of $\mathrm{Ga}_{2} \mathrm{O}_{3}$ on a Si surface with controlled roughness, the first step was to produce groove-like structures on a silicon surface using a photoelectrochemical (PEC) etching technique to fabricate structures with a definite pattern on the surface of the silicon substrate. Then, the wettability properties of Ga were studied on this patterned Si surface in the presence and the absence of a Ag catalyst. 


\section{Materials and Methods}

The substrate was n-type (100) P-doped Si wafer with a thickness of $500 \mu \mathrm{m}$ and a resistivity of 3 to $5 \Omega \cdot \mathrm{cm}$. The Si wafer was cleaned using acetone and methanol for 5 min each in an ultrasonic bath. Photoelectrochemical etching was used to fabricate grooves on silicon surface according to the process developed in previous work [39]. The silicon surface was coated via low pressure chemical vapor deposition (LPCVD) with $\mathrm{Si}_{3} \mathrm{~N}$, which was used as a hard photomask. The substrate was patterned and etched by $\mathrm{KOH}$ to introduce v-groove in the silicon surface for deep etching by PEC etching technique.

Then, the substrate was subjected to the PEC etching process. A 2A high-power multimode fiber-coupled laser with a wavelength of $975 \mathrm{~nm}$ (Qphotonics LLC, Ann Arbor, MI, USA) was used to illuminate the wafer from the backside while etching occurs on the front side of the wafer. An electrochemical technique in HF-based electrolytes was used to fabricate deep microstructures in the patterned substrate. The applied voltage was controlled by $\mathrm{CHI} 660$ electrochemical workstation (CHI Instruments Inc., Austin, TX, USA). The Teflon electrochemical cell contained the electrolyte consisting of $\mathrm{C}_{2} \mathrm{H}_{5} \mathrm{OH}$ $99.9 \%$ and $\mathrm{DI} \mathrm{H}_{2} \mathrm{O}$ with $5 \% \mathrm{HF}$ in a volume ratio of 1:1. Finally, after PEC etching process, the sample was rinsed in deionized water and then dried with nitrogen. Another set of substrates were coated with a layer of $5 \mathrm{~nm} \mathrm{Ag}$ as a catalyst by Lesker sputtering.

To grow $\mathrm{Ga}_{2} \mathrm{O}_{3}$ nanostructures, $0.2 \mathrm{~g}$ of gallium [ $(\mathrm{Ga})$ (purity $99.999 \%$ )] was dripped onto the cleaned PEC-etched silicon surface and on the Ag-coated silicon surface. Figure 1 shows the substrate processing and Ga oxidation process.
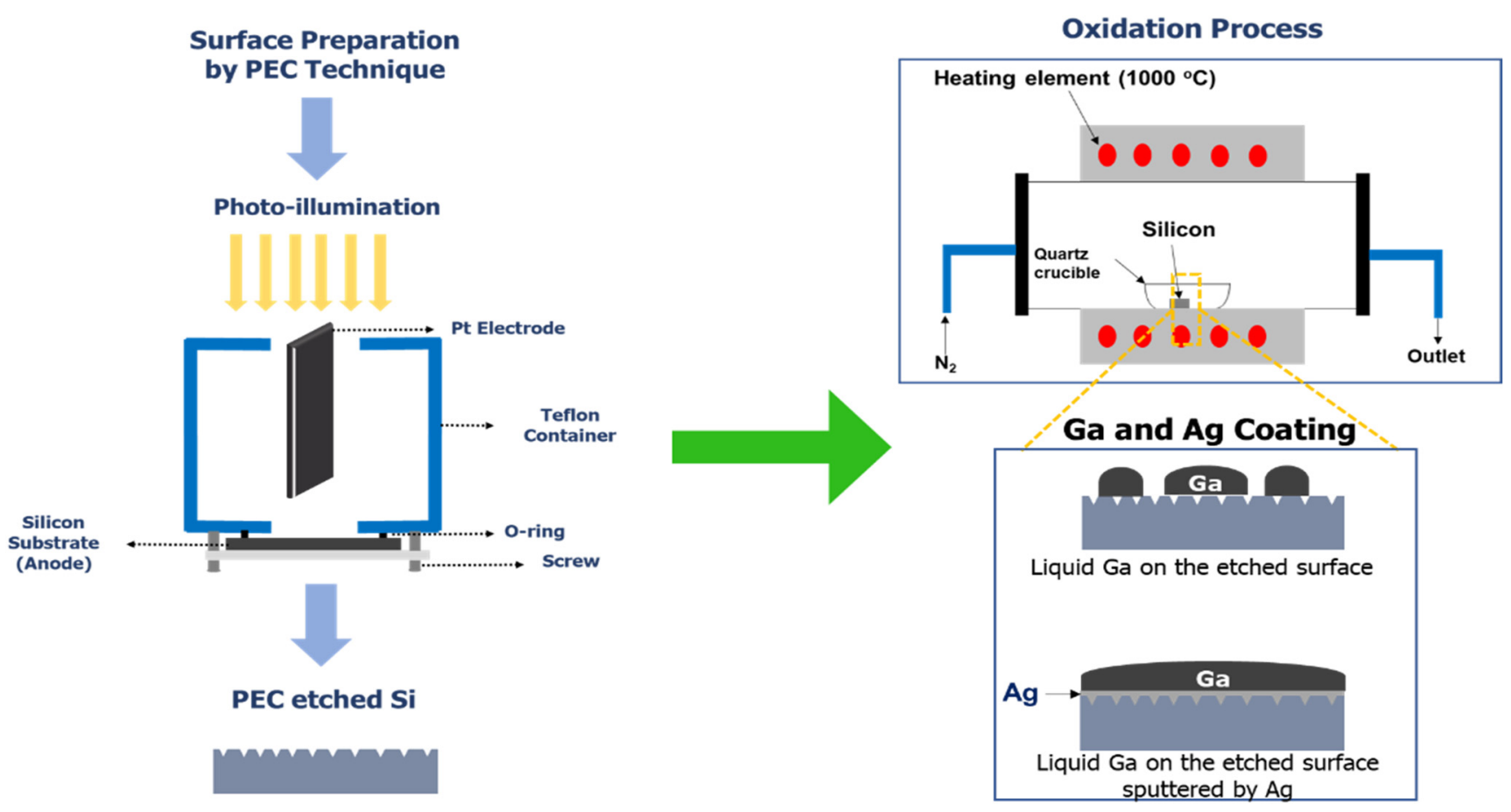

Figure 1. Schematic representation of fabrication and oxidation processes of the silicon substrate and gallium, respectively, including the PEC etching process. Both patterned silicon surface, i.e., with and without a Ag catalyst, were coated with Ga and oxidized at $1000^{\circ} \mathrm{C}$ in $\mathrm{N}_{2}$ gas for $1 \mathrm{~h}$.

The samples were exposed to the heat plate to obtain uniform coating of Ga. The substrate was heated at $1000{ }^{\circ} \mathrm{C}$ for $1 \mathrm{~h}$ in nitrogen flow. All the characterizations were performed at room temperature. Sample was cleaved and analyzed using cross-sectional Scanning Electron Microscopy equipped with a FEI Nova 410 NanoSEM (FEI) system. 


\section{Results and Discussion}

Figure 2 shows the SEM images of gallium oxide on silicon together with two crosssectional views of the spots marked in the top view image. The Ga-Si phase diagram shows an eutectic at 99.994 at. $\% \mathrm{Ga}$ and $29.7^{\circ} \mathrm{C}$ [40]. Heating the $\mathrm{Ga}-\mathrm{Si}$ system at $1000{ }^{\circ} \mathrm{C}$ and then cooling to room temperature results in droplets formed through melting and dewetting at the eutectic temperature. Due to the dewetting effect of liquid Ga on the Si surface, the coverage of the $\mathrm{Ga}_{2} \mathrm{O}_{3}$ nanostructures was not homogenous, as shown in Figure 2. Some Ga drops tend to form small droplets in the range of $1 \mu \mathrm{m}$ on the surface of silicon and not wet it. Ga has high surface tension and does not wet hydrophilic-like surfaces such as silicon. The SEM observation of Ga nanospheres presented in Figure $2 b, c$ suggests a large contact angle $(\alpha)$ close to $180^{\circ}$, which corresponds to low wettability. Under the presence of a small amount of oxygen, some of these Ga nanospheres are oxidized and transformed into nanowires (Figure 2c); however, some of them remained as perfect liquid Ga spheres in the range of 1 to $2 \mu \mathrm{m}$ (Figure $2 \mathrm{~b}$ ).

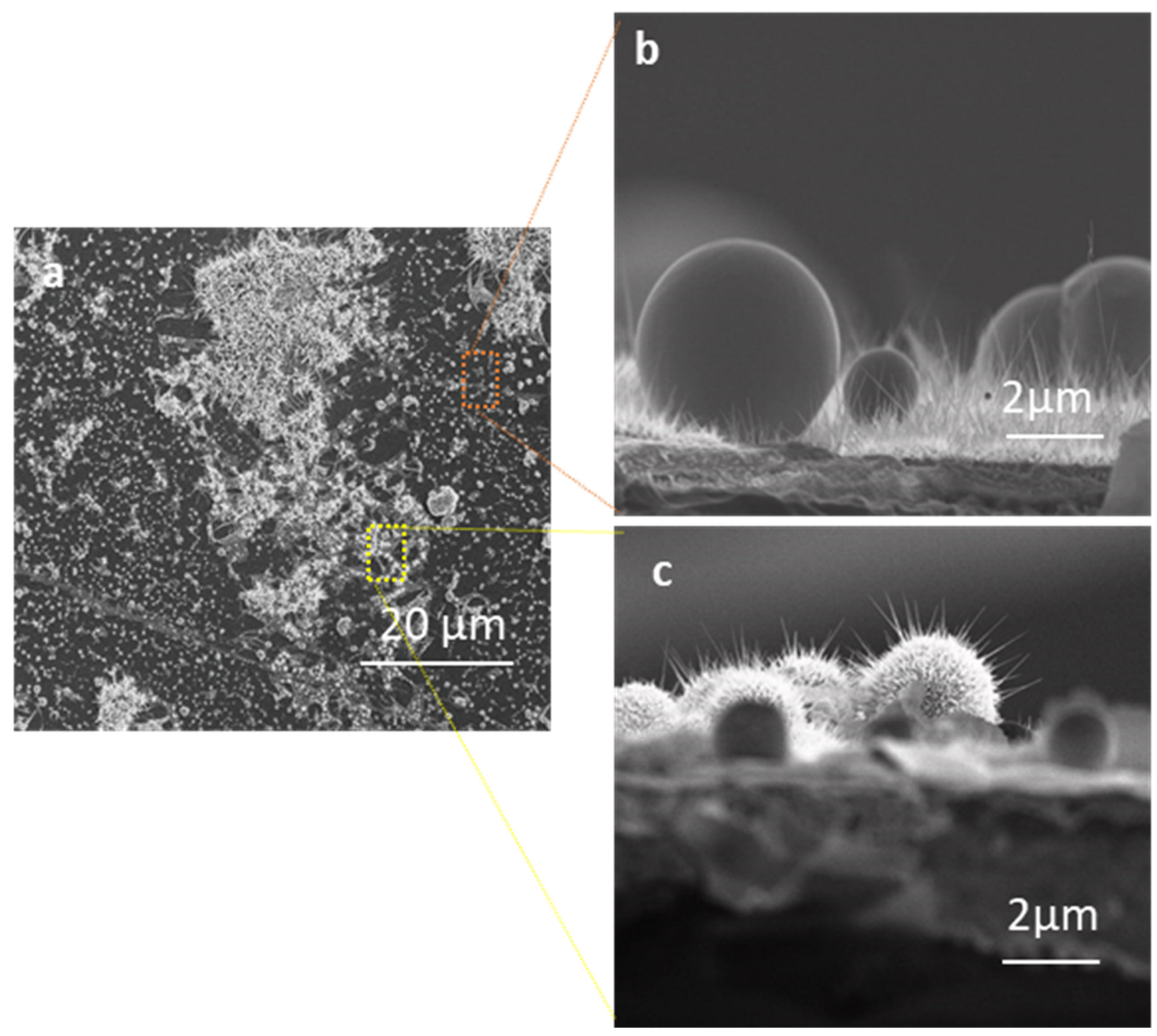

Figure 2. SEM images of $\mathrm{Ga}_{2} \mathrm{O}_{3}$ nanostructures growth on Si surface; (a) Liquid Ga oxidation on silicon surface leads to nonuniform coating; (b) non-oxidized Ga spheres on Si surface; (c) oxidized Ga nanospheres and formation of $\mathrm{Ga}_{2} \mathrm{O}_{3}$ nanowires on the surface. 
To explore the wetting property of liquid Ga on the surface of silicon, grooves with micro- and nanosize structures were introduced on the silicon surface by the PEC etching technique. Figure 3 shows the SEM images of the top and cross-section views of the PEC etched $\mathrm{Si}$ surface, where the diameter and the width of the uniform, concave-shape grooves were $\sim 5.83 \mu \mathrm{m}$ and $\sim 12.10 \mu \mathrm{m}$, respectively.
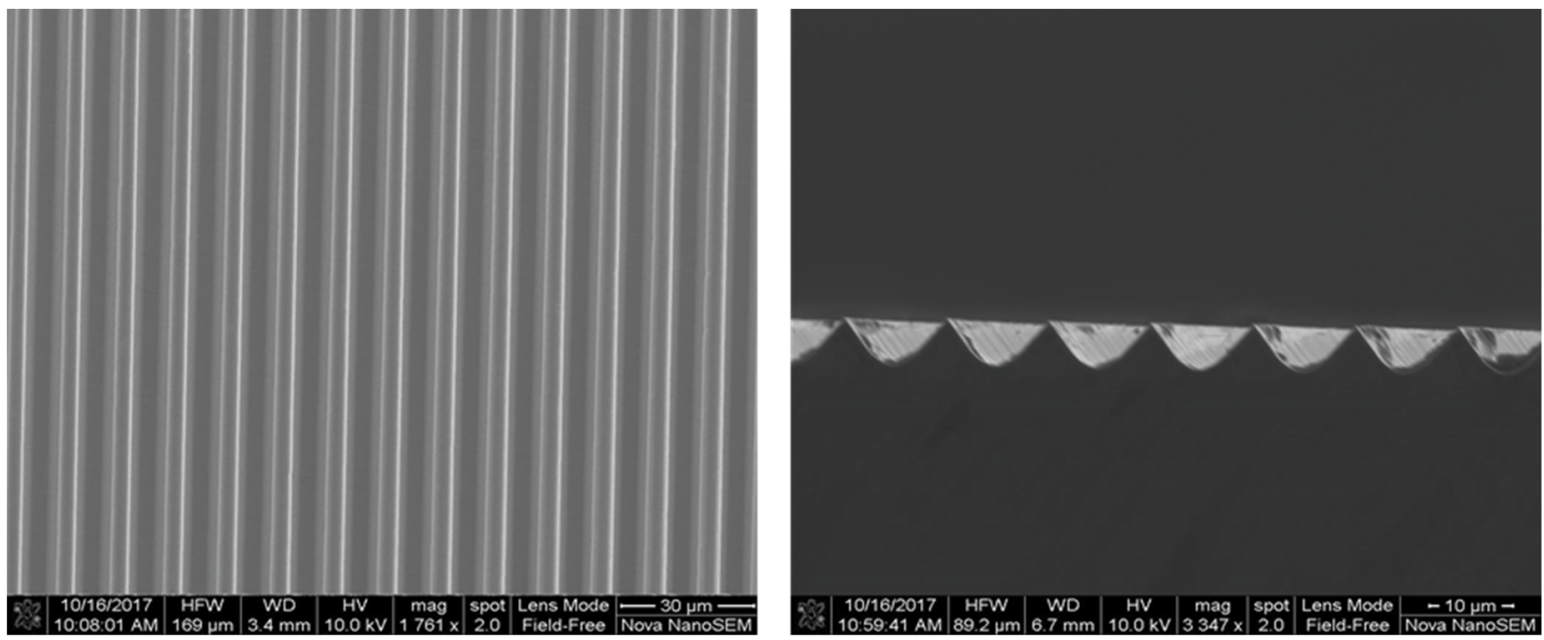

Figure 3. SEM images of groove-shape structures on silicon surface (top view, (left)) and side view (right) of the Si substrate after PEC etching.

Figure 4 shows the SEM images of the oxidized Ga on the PEC-etched surface of Si in the absence and in the presence of a Ag catalyst.
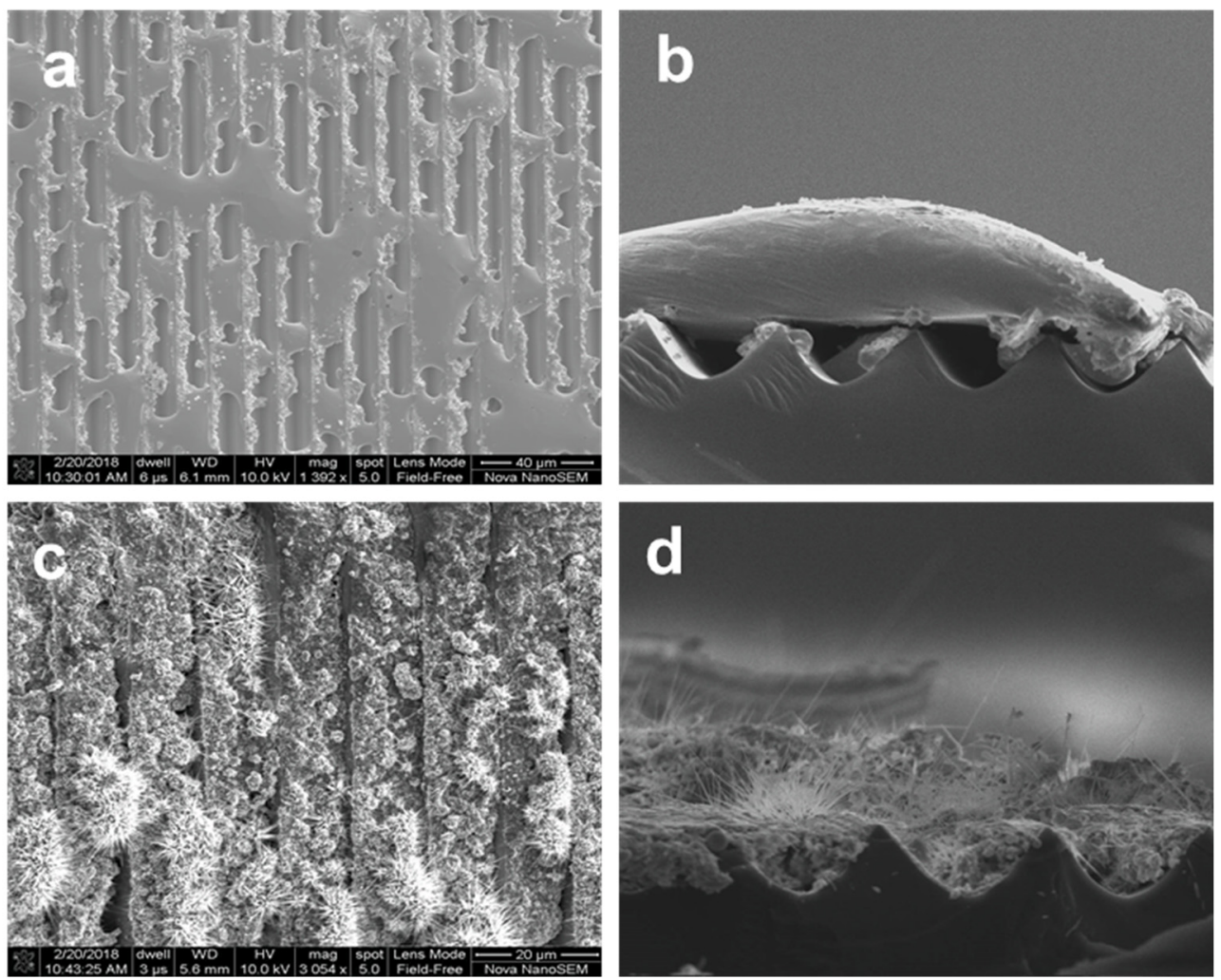

Figure 4. SEM images of the oxidized Ga on PEC-etched surface of Si in the absence $(\mathbf{a}, \mathbf{b})$ and in the presence (c,d) of a Ag catalyst (left: top views; right: cross-section views). 
Although Figure 4a suggests that gallium melts and forms melted-like patches on the PEC-etched Si surface, Figure $4 \mathrm{~b}$ shows that, actually, the liquid gallium does not enter the grooves in the absence of a Ag catalyst. In addition, the liquid gallium oxidation does not take place completely, and the modified surface texture of the silicon actually supports the liquid $\mathrm{Ga}$ and does not allow it to enter the grooves in such condition as shown in Figure 4a,b. By comparison, a major change in the growth morphology of $\mathrm{Ga}_{2} \mathrm{O}_{3}$ nanostructures was observed in the presence of a Ag catalyst, where an increase in the wetting property of liquid Ga was observed. Due to the catalytic action of the Ag layer, $\mathrm{Ga}_{2} \mathrm{O}_{3}$ was grown inside the grooves of the PEC-etched silicon surface (Figure 4c,d), where there was a conformal $\mathrm{Ag}$ layer. In the presence of a $\mathrm{Ag}$ catalyst, a dense growth of nanowires was observed on the top surface and inside the grooves (Figure $4 \mathrm{~d}$ ).

\section{The Growth Mechanism of $\mathrm{Ga}_{2} \mathrm{O}_{3}$ Nanostructures}

During the oxidation process, three major steps are involved in the vapour-liquidsolid (VLS) growth mechanism and in the formation of $\mathrm{Ga}_{2} \mathrm{O}_{3}$. The growth mechanism is summarized in Figure 5.

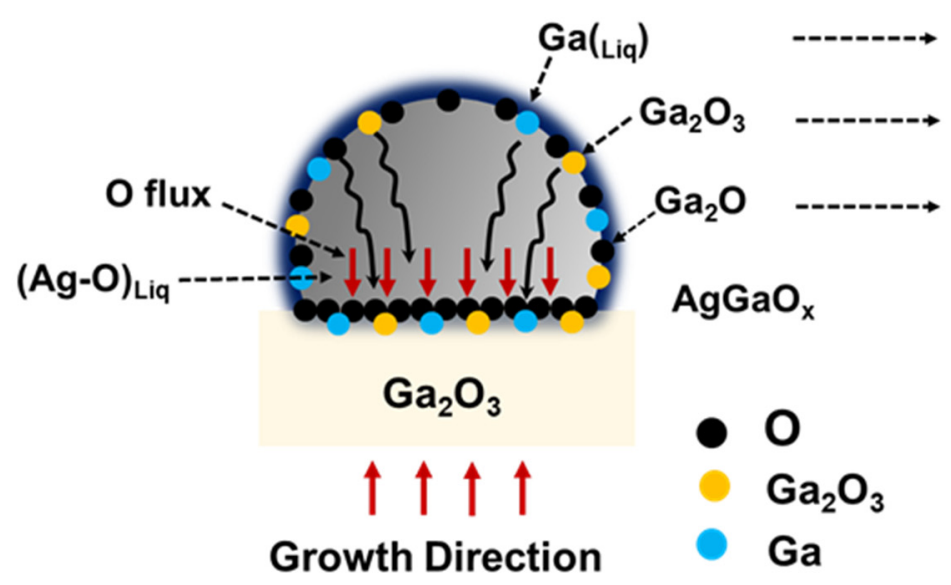

$$
\begin{aligned}
& \text { (1) } 2 \mathrm{Ga}+(3 / 2) \mathrm{O}_{2} \rightarrow \mathrm{Ga}_{2} \mathrm{O}_{3(\mathrm{~s})} \\
& \text { (2) } \mathrm{Ga}_{2} \mathrm{O}_{3(\mathrm{~s})}+4 \mathrm{Ga}_{(1)} \leftrightarrow 3 \mathrm{Ga}_{2} \mathrm{O}_{(\mathrm{g})} \\
& \text { (3) } \mathrm{Ga}_{2} \mathrm{O}_{(\mathrm{g})}+\mathrm{O}_{2(\mathrm{~g})} \rightarrow \mathrm{Ga}_{2} \mathrm{O}_{3(\mathrm{~s})}
\end{aligned}
$$

Figure 5. Growth mechanism and formation of $\mathrm{Ga}_{2} \mathrm{O}_{3}$.

In the first step, liquid gallium oxidizes at the surface of silicon substrate to form gallium (III) oxide $\left(\mathrm{Ga}_{2} \mathrm{O}_{3}\right)$ (Equation (1) in Figure 5) [41,42]. In the second step, the $\mathrm{Ga}_{2} \mathrm{O}_{3}$ solid phase interacts with the gallium liquid phase to form the gallium suboxide $\left(\mathrm{Ga}_{2} \mathrm{O}\right)$ gas phase (Equation (2) in Figure 5) [43]. In the third step, the $\mathrm{Ga}_{2} \mathrm{O}$ vapor phase breaks down into liquid $\mathrm{Ga}$ and $\mathrm{Ga}_{2} \mathrm{O}_{3}$ in the presence of oxygen (Equation (3) in Figure 5) [44,45].

In the presence of a $\mathrm{Ag}$ catalyst, the rate of formation of the solid phase of gallium oxide (III), $\mathrm{Ga}_{2} \mathrm{O}_{3}$, increases significantly. The dissolution and diffusion of oxygen into solid silver [46] is much higher than in liquid Ga [42]. In addition, it has been shown that the oxygen solubility is very high with increasing temperature [47]. At high temperatures, $\mathrm{O}_{2}$ dissociation acts as a pool of $\mathrm{O}$ atoms supply for $\mathrm{Ga}$ oxidation. The $\mathrm{O}_{2}$ concentration gradient would increase to establish a dynamic equilibrium of $\mathrm{Ga}-\mathrm{Ag}-\mathrm{O}$ at $1000{ }^{\circ} \mathrm{C}$. It could be expected that there would be a high concentration of oxygen atoms near the exposed surfaces of the $\mathrm{AgO}_{\mathrm{x}}$ nanoparticles (NPs) and a low oxygen concentration near the $\mathrm{Ag} / \mathrm{Ga}_{2} \mathrm{O}_{3}$ interfaces. Therefore, more oxygen is dissolved in the silver nanoparticle leading to a continuous supply of $\mathrm{Ga}_{2} \mathrm{O}(\mathrm{g})$ and $\mathrm{O}_{2}(\mathrm{~g})$, which increases the formation of the $\mathrm{Ag}-\mathrm{Ga}-\mathrm{O}$ liquid mixture and the growth of $\mathrm{Ga}_{2} \mathrm{O}_{3}$ (s) to spontaneously form denser nanowires [36,48]. It is important to note that high nitrogen $\left(\mathrm{N}_{2}\right)$ pressure $(1-2 \mathrm{GPa})$ and high temperature $\left(1400-1500{ }^{\circ} \mathrm{C}\right)$ is necessary to drive the reaction between $\mathrm{Ga}$ and $\mathrm{N}_{2}$ to form $\mathrm{GaN}$ [49], which was not achieved in our experiments. In addition, our material characterization using XRD and XPS did not show the presence of elemental $\mathrm{N}$ or $\mathrm{GaN}$ [50]. 


\section{Conclusions}

The wettability of liquid gallium and its oxidation on a modified surface of silicon was observed in the presence and absence of a Ag catalyst. A photoelectrochemical etching technique was used to modify the silicon surface by creating concave structures on the surface. In the presence of $\mathrm{Ag}$ catalyst, it was observed that (i) $\mathrm{Ga}_{2} \mathrm{O}_{3}$ tends to form a homogenous coating even within the deep, groove-like structure on the $\mathrm{Si}$ surface, and (ii) an enhanced growth and a high density of nanowires was formed. Hence, this paper presents the first successful attempt to increase the wettability of liquid gallium on the silicon substrate with controlled roughness using the thermal oxidation process to study the effect of surface properties of the growth substrate on the $\mathrm{Ga}_{2} \mathrm{O}_{3}$ morphology.

These observations have a significant impact on the manufacturing of electronic devices. Diverse optoelectronics and electronic applications can use this growth process to create homogenous coatings of the thin film under low temperatures or create conformal coatings of nanowires at high temperatures. Further work on assessing the electrical properties of the $\mathrm{Ga}_{2} \mathrm{O}_{3}$ nanowires grown by this process is ongoing in our group. Such investigations could be further exploited to develop optoelectronic or electronic devices for applications such as gas sensing.

Author Contributions: Conceptualization, B.A.; methodology, B.A.; resources, M.S.I.; writingoriginal draft preparation, B.A. and R.V.; writing-review and editing, B.A., R.V., I.N.P. and D.R.S.; supervision, B.A. and M.S.I. All authors have read and agreed to the published version of the manuscript.

Funding: This research received no external funding.

Institutional Review Board Statement: Not applicable.

Informed Consent Statement: Not applicable.

Conflicts of Interest: The authors declare no conflict of interest.

\section{References}

1. Bringezu, S.; Potočnik, J.; Schandl, H.; Lu, Y.; Ramaswami, A.; Swilling, M.; Suh, S. Multi-Scale Governance of Sustainable Natural Resource Use-Challenges and Opportunities for Monitoring and Institutional Development at the National and Global Level. Sustainability 2016, 8, 778. [CrossRef]

2. Nakagawa, M. Trust in sustainable natural resource development. Nat. Hum. Behav. 2019, 3, 542. [CrossRef]

3. Raipure, S.; Mehetre, D. Wireless sensor network based pollution monitoring system in metropolitan cities. In Proceedings of the 2015 International Conference on Communications and Signal Processing (ICCSP), Melmaruvathur, India, 2-4 April 2015; pp. 1835-1838.

4. Ullah, S.; Branquinho, R.; Mateus, T.; Martins, R.; Fortunato, E.; Rasheed, T.; Sher, F. Solution Combustion Synthesis of Transparent Conducting Thin Films for Sustainable Photovoltaic Applications. Sustainability 2020, 12, 10423. [CrossRef]

5. Fleischer, M.; Meixner, H. Characterization and crystallite growth of semiconducting high-temperature-stable $\mathrm{Ga}_{2} \mathrm{O}_{3}$ thin films. J. Mater. Sci. Lett. 1992, 11, 1728-1731. [CrossRef]

6. Bavasso, I.; Vilardi, G.; Stoller, M.; Chianese, A.; Di Palma, L. Perspectives in Nanotechnology Based Innovative Applications For The Environment. Chem. Eng. Trans. 2016, 47, 55-60.

7. Yu, X.-Y.; Liu, Z.-G.; Huang, X.-J. Nanostructured metal oxides/hydroxides-based electrochemical sensor for monitoring environmental micropollutants. Trends Environ. Anal. Chem. 2014, 3, 28-35. [CrossRef]

8. Tucureanu, M.; Rusănescu, C.; Purdea, L. Polluting Emissions from Incineration and Waste Installations. Rev. Chim. 2019, 70, 2385-2387. [CrossRef]

9. Rusănescu, C.; Murad, E.; Jinescu, C.; Rusanescu, M. The Impact of Biochar on the Soil. Rev. Chim. 2018, 69, 2197-2202. [CrossRef]

10. Enescu, M.; Elena Valentina, S.; Rusănescu, C.; Popescu, I. The Effect of the Action of Impurities Present in Methanol as a Basis for Automobile Fuel and Their Impact on the Environment. Rev. Chim.-Buchar. Orig. Ed. 2019, 70, 4260-4265.

11. Luque, P.; Mántaras, D.A.; Sanchez, L. Artificial Intelligence Applied to Evaluate Emissions and Energy Consumption in Commuter Railways: Comparison of Liquefied Natural Gas as an Alternative Fuel to Diesel. Sustainability 2021, $13,7112$. [CrossRef]

12. Villa, T.F.; Gonzalez, F.; Miljievic, B.; Ristovski, Z.D.; Morawska, L. An Overview of Small Unmanned Aerial Vehicles for Air Quality Measurements: Present Applications and Future Prospectives. Sensors 2016, 16, 1072. [CrossRef]

13. Gardner, J.W.; Wei, G.; Vincent, T.; Volans, K.; Tremlett, P.; Wotherspoon, T.; Dyer, D.C. A Gas Sensor System for Harsh Environment Applications. Procedia Eng. 2015, 120, 275-278. [CrossRef] 
14. Figueiredo, N.M.; Vaz, F.; Cunha, L.; Cavaleiro, A. Au-WO3 Nanocomposite Coatings for Localized Surface Plasmon Resonance Sensing. Materials 2020, 13, 246. [CrossRef] [PubMed]

15. Afzal, A. $\beta-\mathrm{Ga}_{2} \mathrm{O}_{3}$ nanowires and thin films for metal oxide semiconductor gas sensors: Sensing mechanisms and performance enhancement strategies. J. Mater. 2019, 5, 542-557. [CrossRef]

16. Rafique, S.; Han, L.; Zhao, H. (Invited) Ultrawide Bandgap $\beta-\mathrm{Ga}_{2} \mathrm{O}_{3}$ Thin Films: Growths, Properties and Devices. ECS Trans. 2017, 80, 203-216. [CrossRef]

17. Fleischer, M.; Meixner, H. Sensing reducing gases at high temperatures using long-term stable $\mathrm{Ga}_{2} \mathrm{O}_{3}$ thin films. Sens. Actuators $B$ Chem. 1992, 6, 257-261. [CrossRef]

18. Fleischer, M.; Höllbauer, L.; Meixner, H. Effect of the sensor structure on the stability of $\mathrm{Ga}_{2} \mathrm{O}_{3}$ sensors for reducing gases. Sens. Actuators B Chem. 1994, 18, 119-124. [CrossRef]

19. Réti, F.; Fleischer, M.; Perczel, I.V.; Meixner, H.; Giber, J. Detection of reducing gases in air by $\beta-\mathrm{Ga}_{2} \mathrm{O}_{3}$ thin films using self-heated and externally (oven-) heated operation modes. Sens. Actuators B Chem. 1996, 34, 378-382. [CrossRef]

20. Wang, J.C.; Shie, D.C.; Lei, T.F.; Lee, C.L. Turnaround of hysterisis for capacitance-voltage characteristics of hafnium oxynitride dielectrics. Appl. Phys. Lett. 2004, 84, 1531-1533. (In English) [CrossRef]

21. Besleaga, C.; Stan, G.E.; Pintilie, I.; Barquinha, P.; Fortunato, E.; Martins, R. Transparent field-effect transistors based on AlN-gate dielectric and IGZO-channel semiconductor. Appl. Surf. Sci. 2016, 379, 270-276. (In English) [CrossRef]

22. Gao, Z.; Romero, M.F.; Pampillon, M.A.; San Andres, E.; Calle, F. Thermal Assessment of AlGaN/GaN MOS-HEMTs on Si Substrate Using Gd2O3 as Gate Dielectric. IEEE Trans. Electron. Devices 2016, 63, 2729-2734. (In English) [CrossRef]

23. Saeidi, A.; Biswas, A.; Ionescu, A.M. Modeling and simulation of low power ferroelectric non-volatile memory tunnel field effect transistors using silicon-doped hafnium oxide as gate dielectric. Solid-State Electron. 2016, 124, 16-23. (In English) [CrossRef]

24. Tan, X.; Zhou, X.Y.; Guo, H.Y.; Gu, G.D.; Wang, Y.G.; Song, X.B.; Yin, J.Y.; Lv, Y.J.; Feng, Z.H. Excellent-Performance AlGaN/GaN Fin-MOSHEMTs with Self-Aligned Al2O3 Gate Dielectric. Chin. Phys. Lett. 2016, 33, 098501. (In English) [CrossRef]

25. Xiao, D.Q.; He, G.; Liu, M.; Gao, J.; Jin, P.; Jiang, S.S.; Li, W.D.; Zhang, M.; Liu, Y.M.; Lv, J.G.; et al. Modification of optical and electrical properties of sol-gel-derived $\mathrm{TiO}_{2}$-doped $\mathrm{ZrO}_{2}$ gate dielectrics by annealing temperature. J. Alloy. Compd. 2016, 688, 252-259. (In English) [CrossRef]

26. Passlack, M.; Hunt, N.E.J.; Schubert, E.F.; Zydzik, G.J.; Hong, M.; Mannaerts, J.P.; Opila, R.L.; Fischer, R.J. Dielectric-Properties of Electron-Beam Deposited $\mathrm{Ga}_{2} \mathrm{O}_{3}$ Films. Appl. Phys. Lett. 1994, 64, 2715-2717. (In English) [CrossRef]

27. Robertson, J. High dielectric constant oxides. Eur. Phys. J.-Appl. Phys. 2004, 28, 265-291. (In English) [CrossRef]

28. Kaya, A.; Mao, H.; Gao, J.Y.; Chopdekar, R.V.; Takamura, Y.; Chowdhury, S.; Islam, M.S. An Investigation of Electrical and Dielectric Parameters of Sol-Gel Process Enabled beta-Ga $\mathrm{O}_{3}$ as a Gate Dielectric Material. IEEE Trans. Electron. Dev. 2017, 64, 2047-2053. (In English) [CrossRef]

29. Alhalaili, B.; Bunk, R.; Vidu, R.; Islam, S.M. Dynamics Contributions to the Growth Mechanism of $\mathrm{Ga}_{2} \mathrm{O}_{3} \mathrm{Thin}_{\mathrm{Film}}$ and NWs Enabled by Ag Catalyst. Nanomaterials 2019, 9, 1272. [CrossRef]

30. Allen, T.G.; Wan, Y.M.; Cuevas, A. Silicon Surface Passivation by Gallium Oxide Capped With Silicon Nitride. IEEE J. Photovolt. 2016, 6, 900-905. (In English) [CrossRef]

31. Jevasuwan, W.; Maeda, T.; Miyata, N.; Oda, M.; Irisawa, T.; Tezuka, T.; Yasuda, T. Self-limiting growth of ultrathin $\mathrm{Ga}_{2} \mathrm{O}_{3}$ for the passivation of $\mathrm{Al}_{2} \mathrm{O}_{3} / \mathrm{InGaAs}$ interfaces. Appl. Phys. Express 2014, 7, 011201. (In English) [CrossRef]

32. Lin, C.F.; Lin, C.M.; Jiang, R.H. Micro-Square-Array InGaN-Based Light-Emitting Diode with an Insulated $\mathrm{Ga}_{2} \mathrm{O}_{3} \mathrm{Layer}_{\mathrm{e}}$ through a Photoelectrochemical Process. Jpn. J. Appl. Phys. 2012, 51, 01AG03. (In English) [CrossRef]

33. Seok, O.; Ahn, W.; Han, M.K.; Ha, M.W. Effect of $\mathrm{Ga}_{2} \mathrm{O}_{3}$ sputtering power on breakdown voltage of AlGaN/GaN high-electronmobility transistors. J. Vac. Sci. Technol. B 2013, 31, 011203. (In English) [CrossRef]

34. Shih, H.Y.; Chu, F.C.; Das, A.; Lee, C.Y.; Chen, M.J.; Lin, R.M. Atomic Layer Deposition of Gallium Oxide Films as Gate Dielectrics in AlGaN/GaN Metal-Oxide-Semiconductor High-Electron-Mobility Transistors. Nanoscale Res. Lett. 2016, 11, 1-9. (In English) [CrossRef]

35. Ulman, K.; Nguyen, M.T.; Seriani, N.; Gebauer, R. Passivation of surface states of alpha- $\mathrm{Fe}_{2} \mathrm{O}_{3}(0001)$ surface by deposition of $\mathrm{Ga}_{2} \mathrm{O}_{3}$ overlayers: A density functional theory study. J. Chem. Phys. 2016, 144, 094701. (In English) [CrossRef]

36. Alhalaili, B.; Vidu, R.; Islam, M.S. The Growth of $\mathrm{Ga}_{2} \mathrm{O}_{3}$ Nanowires on Silicon for Ultraviolet Photodetector. Sensors $2019,19,5301$. [CrossRef] [PubMed]

37. Detz, H.; Kriz, M.; MacFarland, D.; Lancaster, S.; Zederbauer, T.; Capriotti, M.; Andrews, A.M.; Schrenk, W.; Strasser, G. Nucleation of Ga droplets on Si and SiOx surfaces. Nanotechnology 2015, 26, 315601. (In English) [CrossRef] [PubMed]

38. Glickman, E.; Levenshtein, M.; Budic, L.; Eliaz, N. Interaction of liquid and solid gallium with thin silver films: Synchronized spreading and penetration. Acta Mater. 2011, 59, 914-926. (In English) [CrossRef]

39. Alhalaili, B.; Dryden, D.M.; Vidu, R.; Ghandiparsi, S.; Cansizoglu, H.; Gao, Y.; Saif Islam, M. High-aspect ratio micro- and nanostructures enabled by photo-electrochemical etching for sensing and energy harvesting applications. Appl. Nanosci. 2018, 8, 1171-1177. [CrossRef]

40. Mostafa, A.; Medraj, M. Binary Phase Diagrams and Thermodynamic Properties of Silicon and Essential Doping Elements (Al, As, B, Bi, Ga, In, N, P, Sb and Tl). Materials 2017, 10, 676. [CrossRef]

41. Wang, Y.Z.; Li, N.; Duan, P.P.; Sun, X.W.; Chu, B.L.; He, Q.Y. Properties and Photocatalytic Activity of beta-Ga ${ }_{2} \mathrm{O}_{3} \mathrm{Nannorods}$ under Simulated Solar Irradiation. J. Nanomater. 2015, 2015, 1-5. [CrossRef] 
42. Zinkevich, M.; Aldinger, F. Thermodynamic assessment of the gallium-oxygen system. J. Am. Ceram. Soc. 2004, 87, 683-691. (In English) [CrossRef]

43. Girija, K.; Thirumalairajan, S.; Mastelaro, V.R.; Mangalaraj, D. Catalyst free vapor-solid deposition of morphologically different $\beta-\mathrm{Ga}_{2} \mathrm{O}_{3}$ nanostructure thin films for selective $\mathrm{CO}$ gas sensors at low temperature. Anal. Methods 2016, 8, 3224-3235. [CrossRef]

44. Butt, D.P.; Park, Y.; Taylor, T.N. Thermal vaporization and deposition of gallium oxide in hydrogen. J. Nucl. Mater. 1999, 264, 71-77. (In English) [CrossRef]

45. Kumar, S.; Singh, R. Nanofunctional gallium oxide $\left(\mathrm{Ga}_{2} \mathrm{O}_{3}\right)$ nanowires/nanostructures and their applications in nanodevices. Phys. Status Solidi-Rapid Res. Lett. 2013, 7, 781-792. (In English) [CrossRef]

46. Assal, J.; Hallstedt, B.; Gauckler, L.J. Thermodynamic assessment of the silver-oxygen system. J. Am. Ceram. Soc. 1997, 80, 3054-3060. (In English) [CrossRef]

47. Martienssen, W.W.; Warlimont, H. Springer Handbook of Condensed Matter and Materials Data; Springer: Berlin/Heidelberg, Germany, 2006.

48. Alhalaili, B.; Mao, H.; Dryden, D.M.; Cansizoglu, H.; Bunk, R.J.; Vidu, R.; Woodall, J.; Islam, M.S. Influence of Silver as a Catalyst on the Growth of $\beta-\mathrm{Ga}_{2} \mathrm{O}_{3}$ Nanowires on GaAs. Materials 2020, 13, 5377. [CrossRef]

49. Wang, Y. Current methods for GaN synthesis and the limitations. In Journal of Physics: Conference Series; IOP Publishing: Bristol, UK, 2020; Volume 1676, p. 012002. [CrossRef]

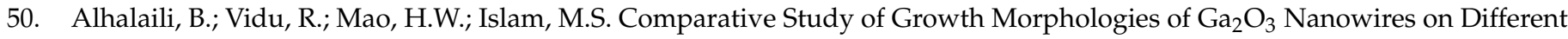
Substrates. Nanomaterials 2020, 10, 1920. [CrossRef] 